\title{
Analisis Faktor-Faktor Yang Memengaruhi Muzaki Dalam Memilih Organisasi Pengelola Zakat (OPZ): Studi Kasus di Badan Amil Zakat Nasional Kota Bogor
}

\section{Analysis of Factors influencing Muzaki in Selecting Zakat Management Organization (ZMO): Case Study in BAZNAS Kota Bogor}

\author{
Nadilla Ambarfauziah Rulian ${ }^{1}$, Lukytawati Anggraeni², Deni Lubis ${ }^{3}$ \\ ${ }^{1}$ Fakultas Ekonomi dan Manajemin IPB, Jl. Raya Darmaga Kampus IPB Darmaga, Bogor, Email : \\ ar.nadilla@gmail.com \\ ${ }^{2}$ Dosen Fakultas Ekonomi dan Manajemin IPB, J1. Raya Darmaga Kampus IPB Darmaga, Bogor, \\ Email :lukytawati.anggraeni@gmail.com \\ ${ }^{3}$ Dosen Fakultas Ekonomi dan Manajemin IPB, Jl. Raya Darmaga Kampus IPB Darmaga, Bogor, \\ Email :denilubis@gmail.com
}

\begin{abstract}
The main purpose of management of zakat in Act No 23/2011 is to achieve public welfare and poverty alleviation. However, until now, zakat has not been sufficient to attain both these goals since zakat fund collected in Indonesia is only about $1 \%$ of its national potential that reaches Rp 217 trillion. This indicates that there are many muslims who are not motivated to pay zakat nor trust Zakat Management Organization. This study analyzes the factors that influence muzakki in choosing Zakat Management Organization and the performance of BAZNAS Kota Bogor from muzakki's perception. Logistic regression is used to analyze the factors that affect muzakki in choosing the Zakat Management Organization. Descriptive analysis is used to analyze the perceptions of the BAZNAS Kota Bogor. This research was conducted during the month of February 2014 with 30 respondents BAZNAS Kota Bogor's muzakki and 30 respondents muzakki whose paying zakat directly to mustahiq. The results of logistic regression show that the factors that affect muzakki in choosing Zakat Management Organization are income, the level of reliability, and institution's image. The muzakki's perception of the performance of BAZNAS Kota Bogor can be concluded as good, particulary in reliability, responsiveness, and tangible.
\end{abstract}

Keywords: Logistic Regression Method, Zakat, Zakat Management Organization (OPZ)

\begin{abstract}
Abstrak. Tujuan utama pengelolaan zakat menurut UU RI No. 23 Tahun 2011 adalah untuk mewujudkan kesejahteraan umum dan penanggulangan kemiskinan. Akan tetapi sampai saat ini zakat belum mencukupi untuk mewujudkan kedua tujuan tersebut, karena dana zakat yang terkumpul di Indonesia hanya berkisar 1\% dari potensi zakat nasional yang mencapai Rp 217 triliun. Hal tersebut menandakan bahwa masih banyak orang Islam yang tidak termotivasi untuk membayar zakat atau umat Islam belum percaya pada OPZ. Studi ini menganalisis faktor-faktor yang memengaruhi muzaki dalam memilih Organisasi Pengelola Zakat (OPZ) dan menganalisis persepsi muzaki terhadap kinerja OPZ. Metode regresi logistik digunakan untuk menganalisis faktor-faktor yang memengaruhi muzaki dalam memilih OPZ. Analisis deskriptif digunakan untuk menganalisis persepsi muzaki terhadap OPZ. Penelitian ini dilakukan selama bulan Februari 2014 dengan 30 responden muzaki BAZNAS Kota Bogor dan 30 muzaki yang membayarkan zakatnya langsung ke mustahik. Hasil regresi logistik menunjukkan bahwa faktor-faktor yang memengaruhi muzaki dalam memilih OPZ adalah pendapatan, tingkat realiability, dan citra lembaga. Walau demikian, persepsi muzaki terhadap kinerja OPZ dapat disimpulkan sudah cukup baik, khususnya terkait reliability, responsiveness, dan tangible.
\end{abstract}

Kata kunci: Metode Regresi Logistik, Zakat, Organisasi Pengelola Zakat (OPZ)

\section{Pendahuluan}

Undang-Undang Republik Indonesia Nomor 23 Tahun 2011 Tentang Pengelolaan Zakat menjelaskan bahwa lembaga zakat di Indonesia terbagi menjadi dua, yaitu Badan Amil Zakat dan Lembaga Amil Zakat. Badan Amil Zakat Nasional (BAZNAS) merupakan lembaga yang dibentuk oleh pemerintah yang bertugas untuk mengelola zakat secara nasional, sedangkan Lembaga Amil Zakat (LAZ) merupakan lembaga yang dibentuk oleh masyarakat yang tujuannya adalah mengumpulkan, mendistribusikan, dan mendayagunakan dana zakat. 
Pengelolaan dana zakat yang baik oleh lembaga, dapat menjadikan zakat sebagai instrumen ekonomi yang memiliki kekuatan untuk mengentaskan kemiskinan, pembukaan lapangan kerja, peningkatan pendapatan, dan mendorong tumbuhnya perekonomian masyarakat (Muhammad 2009). Hal tersebut dapat diwujudkan dengan meningkatkan jumlah penerimaan zakat di lembaga dengan terus melakukan upaya penggalian dana zakat (Hafidhuddin 2002).

Pengumpulan dana zakat yang optimal untuk saat ini masih sulit untuk dilakukan, dapat dilihat dari hasil riset BAZNAS dan FEM IPB yang mengungkapkan bahwa total potensi zakat nasional adalah Rp217 Triliun (Tabel 1), namun dana zakat yang dapat terserap di Indonesia hanya sekitar 1\% dari potensi zakat nasional (Hafidhuddin 2013).

Tabel 1 Potensi Zakat Nasional

\begin{tabular}{lr}
\hline \multicolumn{1}{c}{ Keterangan } & Potensi Zakat (Triliun Rupiah) \\
\hline Potensi Zakat Rumah Tangga & 82.70 \\
Potensi Zakat Industri Swasta & 114.89 \\
Potensi Zakat BUMN & 2.40 \\
Potensi Zakat Tabungan & 17.00 \\
Total Potensi Zakat Nasional & 217.00 \\
\hline
\end{tabular}

Sumber : Beik dalam Alhasanah 2011

Kesenjangan yang sangat besar antara dana zakat yang terkumpul dan potensi zakat yang ada menandakan bahwa masih banyak orang Islam yang tidak termotivasi untuk membayar zakat. Penyebab lain dari sedikitnya dana zakat yang terkumpul dan tidak mencukupi untuk mengentaskan kemiskinan adalah umat tidak percaya kepada lembaga pengelola zakat (Mawardi 2005). Padahal lembaga zakat sangat berpengaruh dalam pengoptimalan potensi zakat (Gamsir et al. 2012). Lembaga zakat saat ini sudah banyak yang dapat meraih prestasi dengan inovasi program-programnya untuk pengumpulan zakat dan pengelolaan zakat, salah satunya adalah BAZNAS Bogor. BAZNAS Bogor merupakan salah satu lembaga zakat daerah yang banyak meraih prestasi dan mampu mengumpulkan dana zakat yang terus meningkat dari tahun ke tahun.

Dana zakat yang terkumpul di suatu lembaga pengelola zakat dapat didistribusikan ke delapan ashnaf dalam berbagai inovasi progam. Sehingga, semakin banyak dana yang terkumpul semakin banyak pula program-program yang terealisasi untuk menyejahterakan delapan ashnaf. Saat ini dalam pengumpulan dana zakat, BAZNAS Kota Bogor telah mengalami banyak kemajuan, terlihat dari meningkatnya dana ZIS yang terkumpul pada tahun 2011 - 2012 (Tabel 2). Akan tetapi tetap saja dana tersebut masih jauh dari potensi zakat yang sebenarnya, yaitu masih di kisaran $1 \%$ dari potensi zakat sebenarnya.

Tabel 2 Perkembangan Data Penerimaan Dana Zakat Infak Sedekah BAZNAS Kota Bogor Tahun 2011-2012

\begin{tabular}{lrrr}
\hline \multirow{2}{*}{ Uraian } & \multicolumn{2}{c}{ Jumlah Penerimaan (Rupiah) } & Perkembangan \\
\cline { 2 - 4 } & \multicolumn{1}{c}{ Tahun 2011 } & \multicolumn{1}{c}{ Tahun 2012 } & \multicolumn{1}{c}{$(\%)$} \\
\hline Zakat & $2,124,143,462$ & $2,192,540,539,94$ & 3.22 \\
Infak/Sedekah & $558,801,060$ & $588,285,937,44$ & 5.27 \\
Total Penerimaan ZIS & $2,682,944,522$ & $2,780,826,477,38$ & 3.65 \\
\hline
\end{tabular}

Sumber : BAZNAS Kota Bogor, 2012 (diolah) 
Sebelumnya telah dilakukan beberapa penelitian mengenai faktor-faktor yang memengaruhi muzaki dalam memilih lembaga zakat, namun belum ada penelitian mengenai hal tersebut yang dilakukan di BAZNAS Kota Bogor. BAZNAS Kota Bogor merupakan salah satu lembaga zakat daerah yang banyak meraih prestasi, diantaranya adalah (BAZNAS Kota Bogor, 2013) :

1. BAZ kota/kabupaten terbaik tingkat nasional untuk kategori keativitas program pendayagunaan versi BAZNAS pada tahun 2009

2. BAZ kota/kabupaten terbaik peringkat dua tingkat nasional versi Islamic Social Responsibility pada tahun 2010

3. BAZNAS daerah terbaik kedua se-Indonesia versi Forum Zakat dan Masyarakat Ekonomi Syariah pada tahun 2013

Penelitian terdahulu yang dilakukan oleh Jaelani (2008) menyimpulkan bahwa kualitas pelayanan zakat dan social marketing secara bersama-sama mempunyai pengaruh yang signifikan terhadap keputusan berzakat muzaki. Kualitas pelayanan dibagi kepada beberapa indikator, yaitu kemampuan untuk memberikan jasa yang akurat dan terpercaya (Realiability), kebijakan untuk membantu dan memberikan pelayanan yang cepat dan responsif kepada muzaki (Responsiveness), kepercayaan, pengetahuan, dan keramahan karyawan serta kemampuan melaksanakan tugas secara spontan sehingga menimbulkan kepercayaan dan keyakinan nasabah (Assurance), memberikan perhatian yang bersifat individual kepada muzaki dan berupaya untuk memahami keinginan muzaki (Emphaty), dan penampilan dan kemampuan sarana dan prasarana fisik (Tangible).

Penelitian terdahulu yang dilakukan di Kabupaten Bogor oleh Mukhlis (2010) menyimpulkan bahwa faktor yang memengaruhi individu untuk membayar zakat di Organisasi Pengelola Zakat (OPZ) adalah karena OPZ bersifat transparan, profesional, memberi kemudahan dalam berzakat, serta pelayanan yang memuaskan. Sebaliknya, individu yang lebih memilih membayar langsung ke penerima zakat memiliki penilaian yang kurang baik terhadap organisasi zakat. Adapun hal-hal yang memengaruhi responden dalam memilih tempat berzakat, yaitu adanya kemudahan dari OPZ, baiknya kinerja OPZ yang dicerminkan oleh transparansi, profesionalitas, dan sosialisasi dari OPZ.

Berdasarkan uraian tersebut, maka permasalahan yang akan dijawab dalam penelitian ini adalah :

1. Bagaimana persepsi muzaki terhadap kinerja Badan Amil Zakat Nasional kota Bogor ?

2. Faktor-faktor apa saja yang memengaruhi muzaki dalam memilih Organisasi Pengelola Zakat (OPZ) ?

Berdasarkan latar belakang dan permasalahan tersebut, penelitian ini bertujuan untuk :

1. Menganalisis persepsi muzaki terhadap kinerja Badan Amil Zakat Nasional kota Bogor

2. Menganalisis faktor-faktor yang memengaruhi muzaki dalam memilih Organisasi Pengelola Zakat (OPZ)

\section{Tinjauan Pustaka}

Ditinjau dari segi fikih, zakat merupakan sejumlah harta yang diwajibkan Allah untuk diserahkan kepada yang berhak (Qardhawi 1993). Selanjutnya, ditinjau dari segi istilah, zakat adalah bagian dari harta dengan persyaratan tertentu yang diwajibkan oleh Allah Swt. untuk diserahkan kepada yang berhak menerimanya, dengan persyaratan tertentu (Hafidhuddin 2002). Zakat juga merupakan salah satu bentuk ibadah dengan menggunakan harta yang mendorong umat muslim untuk mengasihi sesama, mewujudkan keadilan sosial, mendayakan masyarakat, menggerakan perekonomian masyarakat, serta untuk mengentaskan kemiskinan (Arifin 2011).

Zakat merupakan kewajiban yang tegas dan mutlak, karena dalam zakat terkandung hikmah dan manfaat yang sangat besar dan mulia, baik bagi pemberi zakat (muzaki), penerima zakat 
(mustahik), harta benda yang dikeluarkan zakatnya, maupun bagi masyarakat. Adapun hikmah, urgensi, dan manfaaat zakat, yaitu (Hafidhuddin 2007) :

1. Zakat sebagai wujud iman kepada Allah SWT., syukur terhadap nikmat-Nya, menumbuhkan akhlak mulia, menghilangkan sifat kikir dan rakus, menumbuhkan ketenangan hidup, mengembangkan dan menyucikan harta, menumbuhkan keberkahan harta, serta pintu rejeki akan selalu dibuka oleh Allah swt.

2. Zakat merupakan hak bagi mustahik yang berfungsi untuk menolong, membantu, dan membina mereka ke arah kehidupan yang lebih baik dan lebih sejahtera. Keberadaan zakat diharapkan mampu memenuhi kebutuhan mustahik, terutama kaum fakir miskin dan menghilangkan atau memperkecil penyebab kemiskinan.

3. Zakat sebagai penghubung antara kelompok yang berkecukupan hidupnya dengan para pejuang di jalan Allah yang waktunya sepenuhnya digunakan untuk berjuang di jalan Allah dan tidak memiliki waktu yang cukup untuk menafkahi diri maupun keluarganya.

4. Zakat sebagai salah satu sumber dana bagi pembangunan sarana dan prasarana umat Islam, yaitu sarana pendidikan, kesehatan, sosial-ekonomi, dan peningkatan kualitas sumber daya manusia.

5. Zakat untuk memasyarakatkan etika bisnis yang benar, karena zakat hanya diterima dari harta yang halal.

6. Zakat merupakan salah satu instrumen pemerataan pendapatan, dengan pengelolaan zakat yang baik dimungkinkan untuk membangun pertumbuhan ekonomi dan pemerataan pendapatan. Keberadaan zakat menjadi penyebab harta akan selalu beredar dan mencegah terjadinya pemusatan harta pada satu tangan saja, serta mendorong manusia untuk melakukan investasi.

Orang-orang yang berhak mendapatkan zakat atau disebut sebagai ashnaf juga sudah ditentukan dalam Al-Qur'an, yaitu orang-orang fakir, orang-orang miskin, pengurus-pengurus zakat, para mualaf yang dibujuk hatinya, untuk (memerdekakan) budak, orang-orang yang berutang, untuk jalan Allah dan orang-orang yang sedang dalam perjalanan. (QS.At-Taubah [9] : 60).

Salah satu golongan yang berhak mendapatkan zakat adalah pengurus-pengurus zakat (amilin). Imam al-Qurthubi menafsirkan bahwa amil dalam ayat tersebut adalah orang-orang yang ditugaskan untuk mengambil, menuliskan, menghitung dan mencatat zakat yang diambilnya dari muzaki untuk diberikan kepada yang berhak menerima zakat (Hafidhuddin 2007). Sejak zaman pemerintahan Rasulullah saw., pengelolaan dana zakat sudah diserahkan kepada amil di Baitul Mal, yaitu lembaga yang mengumpulkan dan mendistribusikan semua hasil penghimpunan kekayaan negara (Amalia 2010).

Indonesia memiliki dua macam organisasi pengelola zakat yang bertugas untuk melakukan kegiatan perencanaan, pengorganisasian, pelaksanaan, dan pengawasan terhadap pengumpulan, pendistribusian, dan pendayagunaan zakat, yaitu Badan Amil Zakat (BAZ) yang dibentuk oleh pemerintah dan Lembaga Amil Zakat (LAZ) yang dibentuk oleh masyarakat. BAZ maupun LAZ memiliki misi yang sama, yaitu mewujudkan kesejahteraan masyarakat dan keadilan sosial. Hal tersebut merupakan salah satu bentuk bukti kepedulian Islam terhadap kaum tidak berpunya, yaitu dengan menghadirkan lembaga zakat yang berfungsi sebagai tempat untuk mengumpulkan dan mendistribusikan dana kepada masyarakat yang membutuhkan (Hidayat 2010).

Ada beberapa hal yang menjadi pertimbangan dalam pengelolaan zakat melalui lembaga, yaitu (Hafidhuddin 2002) :

1. Menjamin kepastian dan disiplin pembayaran zakat

2. Menjaga perasaan mustahik bila berhadapan langsung untuk menerima haknya dari muzaki

3. Mencapai efisiensi, efektivitas, dan sasaran yang tepat dalam pendistribusian zakat

4. Memperlihatkan syiar Islam dan semangat penyelenggaraan negara dan pemerintahan yang islami. Sebaliknya, jika zakat diserahkan langsung dari muzaki ke mustahik tanpa campur 
tangan lembaga, maka nasib dan hak para mustahik terhadap muzaki tidak mendapatkan jaminan pasti.

Potensi zakat di Indonesia yang mencapai 217 Trilliun merupakan jumlah yang sangat besar dan mampu secara finansial memecahkan masalah kemiskinan dan ketidakadilan di Indonesia, namun sampai saat ini zakat yang terkumpul di lembaga pengelola zakat hanya sekitar $1 \%$ dari potensi yang ada. Hal tersebut disebabkan karena banyak masalah dalam memobilisasi zakat di Indonesia, diantaranya (Damanhuri 2010) :

1. Trauma psikologis, banyak kasus di Indonesia dimana zakat yang terkumpul tidak sampai ke kaum fakir miskin

2. Belum ada visi dan langkah besar yang mengaitkan pengumpulan dana zakat dengan langkah memecahkan kemiskinan dan ketidakadilan sosial baik nasional maupun per daerah

3. Belum adanya sinergi antara gerakan zakat dengan program pemerintah

\section{Metode Penelitian}

\subsection{Lokasi dan Waktu Penelitian}

Penelitian ini dilakukan di Badan Amil Zakat Nasional Bogor (BAZNAS Kota Bogor). Pemilihan lokasi penelitian dilakukan berdasarkan wilayah penghimpunan zakat BAZNAS Kota Bogor. Pemilihan BAZNAS Kota Bogor tersebut dilakukan secara purposive (sengaja) dengan beberapa pertimbangan, yaitu BAZNAS Kota Bogor yang merupakan salah satu lembaga pengelola zakat terbaik di Indonesia dan telah menghimpun dana zakat, infak, dan sedekah (ZIS) yang terus meningkat dari tahun ke tahun. Penelitian dilakukan selama bulan Februari 2014.

\subsection{Jenis dan Sumber Data}

Jenis data yang digunakan dalam penelitian ini adalah data primer dan data sekunder. Data primer diperoleh dari hasil wawancara dengan muzaki yang membayarkan zakatnya di BAZNAS Kota Bogor dan yang membayarkan zakatnya langsung ke mustahik, data tersebut digunakan untuk mengetahui faktor-faktor yang memengaruhi muzaki dalam memilih lembaga pengelola zakat dan persepsi muzaki terhadap kinerja BAZNAS Kota Bogor. Selanjutnya data sekunder digunakan untuk melengkapi data primer. Sumber data lain yang digunakan dalam penelitian ini didapatkan melalui BAZNAS Kota Bogor, buku, jurnal, skripsi, tesis, dan internet.

\subsection{Metode Pengumpulan Data}

Data dalam penelitian ini diambil dengan metode studi kasus (case study) melalui wawancara kepada muzaki yang menjadi responden dengan menggunakan kuesioner. Pengambilan sampel dilakukan dengan teknik pengambilan sampel non acak, yaitu prosedur memilih sampel berdasarkan pertimbangan karakteristik tertentu yang cocok dan diperlukan untuk menjawab penelitian (Juanda 2009). Karakteristik yang diambil dalam penelitian ini adalah muzaki rumah tangga yang rutin membayarkan zakat maalnya, yaitu sebanyak 30 responden muzaki yang membayarkan zakatnya di BAZNAS Kota Bogor dan 30 muzaki yang membayarkan zakatnya langsung kepada mustahik.

\subsection{Metode Pengolahan dan Analisis Data}

Metode analisis data yang digunakan dalam penelitian ini menggunakan dua pendekatan, yaitu pendekatan analisis kuantitatif dan pendekatan analisis kualitatif. Pendekatan analisis kuantitatif digunakan untuk menampilkan data dalam bentuk tabel, sedangkan pendekatan analisis kualitatif digunakan untuk mengumpulkan data-data fakta dari hasil wawancara dan kuesioner yang didapat dari muzaki. 


\subsection{Analisis Persepsi Muzaki terhadap Kinerja BAZNAS Kota Bogor}

Metode yang digunakan untuk menganalisis persepsi muzaki terhadap kinerja BAZNAS Kota Bogor adalah metode deskriptif, yaitu dengan melihat kepuasan muzaki terhadap kinerja BAZNAS Kota Bogor. Sampel dalam analisis ini adalah muzaki yang membayarkan zakatnya di BAZNAS Kota Bogor. Kinerja yang dilihat dalam analisis persepsi ini adalah kualitas pelayanan, program penyaluran, dan fasilitas yang disediakan oleh BAZNAS Kota Bogor.

Kualitas pelayanan yang dimaksud dilihat dari Reliability (kehandalan), Responsiveness (ketanggapan), Assurance (jaminan), Empathy (empati), dan Tangible (wujud sarana dan prasarana fisik). Program penyaluran dilihat dari program penyaluran yang tersedia di BAZNAS Kota Bogor. Fasilitas dilihat dari akses yang disediakan BAZNAS Kota Bogor untuk memudahkan muzaki dalam membayar zakat dan mendapatkan informasi. Penilaian atas kepuasan muzaki terhadap kinerja BAZNAS Kota Bogor dinilai menggunakan skala likert, yaitu skala yang digunakan untuk mengukur sikap, pendapat, atau persepsi seseorang mengenai gejala sosial tertentu. Skala likert digunakan untuk mengukur variabel yang

akan dijabarkan menjadi sub variabel yang memiliki indikator terukur, yaitu sebagai berikut (Riduwan 2008) :

1 = Sangat Tidak Setuju

2 = Tidak Setuju

$3=$ Kurang Setuju

$4=$ Setuju

$5=$ Sangat Setuju

\subsection{Analisis Faktor-faktor yang Memengaruhi Muzaki dalam Memilih Lembaga Zakat}

Uji beda digunakan untuk menganalisis hubungan antara variabel independen dengan kasus 2 sampel berpasangan. Dengan menggunakan uji beda maka dapat diketahui apakah populasi berdasarkan dua sampel berpasangan tersebut berbeda (Firdaus et al. 2011). Metode analisis data yang digunakan untuk menganalisis faktor-faktor yang memengaruhi muzaki dalam memilih OPZ adalah model logit atau regresi logistik. Model logit digunakan ketika variabel dependen bersifat kualitatif. Jika variabel kualitatif tersebut hanya mempunyai dua kemungkinan nilai maka model yang digunakan adalah binary logistic. Model logit dalam penelitian ini dapat digunakan untuk menganalisis faktor-faktor yang memengaruhi muzaki dalam memilih organisasi pengelola zakat, yaitu berdasarkan model yang dikembangkan dari penelitian Jaelani (2008). Model logit diturunkan berdasarkan fungsi peluang logistik kumulatif yang dispesifikasikan sebagai berikut (Juanda 2009) :

$P_{i}=F\left(Z_{i}\right)=F\left(\alpha+\beta X_{i}\right)=\quad \frac{1}{1+e^{-(\alpha+\beta X i)}}$

Keterangan :

$\mathrm{P}_{\mathrm{i}}=$ Keputusan muzaki memilih tempat membayar zakat $(1=$ memilih $\mathrm{OPZ}, 0=$ tidak memilih

OPZ)

$\alpha=$ Intersep

$\beta_{\mathrm{i}}=$ Parameter peubah $\mathrm{X}_{\mathrm{i}}$

$\mathrm{X}_{1} \quad=\quad$ Umur responden (tahun)

$\mathrm{X}_{2}=$ Dummy Jenis Kelamin; $(1=$ laki-laki dan $0=$ perempuan $)$

$\mathrm{X}_{3}=$ Jumlah Tanggungan (orang)

$\mathrm{X}_{4}=$ Lama pendidikan (tahun)

$\mathrm{X}_{5}=$ Pendapatan (Rupiah)

$\mathrm{X}_{6}=\operatorname{Jarak}(\mathrm{km})$ 


$\begin{array}{lll}\mathrm{X}_{7} & = & \text { Citra Lembaga (skor) } \\ \mathrm{X}_{8} & = & \text { Pengetahuan (skor) } \\ \mathrm{X}_{9} & = & \text { Program Penyaluran Zakat (skor) } \\ \mathrm{X}_{10} & = & \text { Realiability (skor) } \\ \mathrm{X}_{11} & = & \text { Responsiveness (skor) } \\ \mathrm{X}_{12} & = & \text { Assurance (skor) } \\ \mathrm{X}_{13} & = & \text { Emphaty (skor) } \\ \mathrm{X}_{14} & = & \text { Tangible (skor) } \\ \mathrm{X}_{15}= & \text { Akses (skor) } \\ \mathrm{X}_{16}= & \text { Promosi Lembaga (skor) }\end{array}$

Odd Ratio adalah rasio peluang terjadinya pilihan 1 (memilih OPZ) terhadap peluang terjadinya pilihan 0 (tidak memilih OPZ). Nilai odds menjadi suatu nilai indikator kecenderungan muzaki untuk menentukan pilihan 1 (memilih OPZ). Nilai odds semakin besar menandakan bahwa peluang muzaki untuk memilih OPZ semakin besar. Hubungan antara parameter dan odds ratio yaitu :

$$
\text { OddsRasio }=\frac{P_{i}}{1-P_{i}}
$$

Keterangan :

$\mathrm{P}_{\mathrm{i}} \quad=\quad$ Rasio peluang terjadi pilihan 1

\section{Pembahasan}

Penghimpunan dana Zakat Infaq Shodaqoh (ZIS) yang dikumpulkan BAZNAS Bogor mengalami peningkatan selama bulan Ramadhan dari tahun ke tahun (Tabel 3). Total penerimaan ZIS dari tahun 2011 ke tahun 2012 meningkat sebesar 26.6\%, sedangkan dari tahun 2012 ke tahun 2013 meningkat sebesar 27.85\%. Perkembangan penerimaan terbesar terdapat pada penerimaan Infaq Shodaqoh pada tahun 2012 yang meningkat $109.3 \%$ dari tahun sebelumnya.Unit Pengelola Zakat (UPZ) juga turut mengalami peningkatan, pada tahun 2012 UPZ yang ada di masjid-masjid kota Bogor telah tercatat ada 119 masjid, sedangkan di tahun 2013 ini total UPZ mencapai kisaran 150 masjid, perkembangannya mencapai $26 \%$.

Tabel 3 Perkembangan Data Penerimaan Dana ZIS BAZNAS Bogor

\begin{tabular}{lrrrc}
\hline \multirow{2}{*}{ Uraian } & \multicolumn{3}{c}{ Jumlah Penerimaan } & Perkembangan \\
\cline { 2 - 5 } & Tahun 2011 & Tahun 2012 & Tahun 2013 & $(\%)$ \\
\hline Zakat Maal & 2.757 & 2.787 & 3.058 & 5.39 \\
Zakat Fitrah & 1.364 & 1.184 & 1.952 & 24.8 \\
Infaq/Shodaqoh & 1.506 & 3.153 & 4.099 & 69.65 \\
Total & 5.628 & 7.125 & 9.110 & 27.05 \\
Penerimaan & & & & \\
\hline
\end{tabular}

Sumber : BAZNAS Kota Bogor, 2013 (diolah)

Karakteristik responden berdasarkan tingkat usia, lama pendidikan, dan jumlah tanggungan ditampilkan dalam bentuk statistik deskriptif pada Tabel 4. Statistik deskriptif ditampilkan untuk mengetahui karakteristik data berdasarkan pada ukuran pemusatan dan penyebaran data. Ukuran standar deviasi digunakan untuk menggambarkan variasi data. 
Tabel 4 Statistik Deskriptif Karakteristik Responden

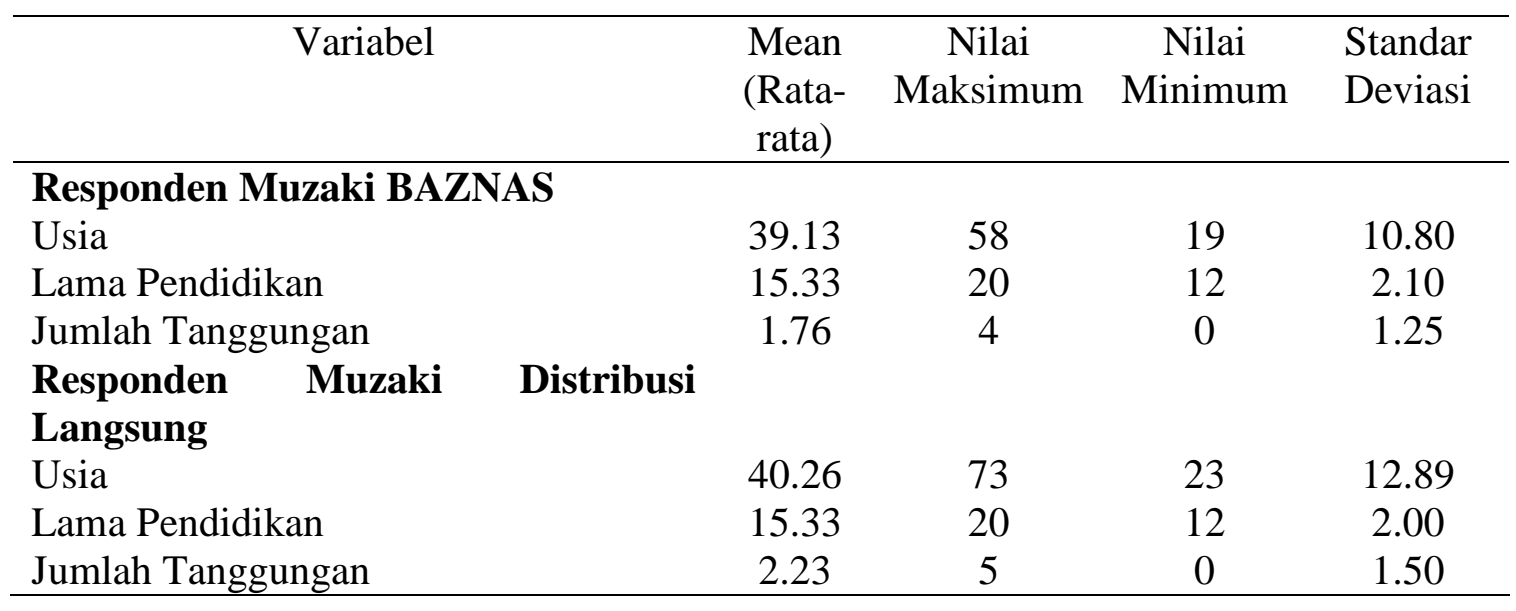

Hasil tersebut menunjukkan bahwa rata-rata usia responden Muzaki Distribusi Langsung sedikit lebih tinggi dibandingkan dengan responden muzaki BAZNAS, serta menghasilkan nilai standar deviasi yang berbeda pula. Rata-rata usia responden Muzaki Distribusi Langsung adalah 40 tahun dengan nilai standar deviasi sebesar 12.89 tahun. Rata-rata usia responden muzaki BAZNAS Kota Bogoradalah 39 tahun dengan nilai standar deviasi sebesar 10.80 tahun. Lama pendidikan responden muzaki BAZNAS Kota Bogordan Muzaki Distribusi Langsung memiliki nilai rata-rata yang sama, yaitu 15.33. Nilai rata-rata lama pendidikan responden adalah 15 tahun atau setara dengan lulusan D3 dengan lama pendidikan tertinggi yaitu 20 tahun atau setara dengan lulusan S3 dan terendah yaitu 12 tahun atau setara dengan lulusan SMA. Jumlah tanggungan dari responden terdiri dari orang yang biaya hidupnya ditanggung oleh responden. Hasil penelitian menunjukan bahwa sebesar $73.33 \%$ atau 22 orang responden muzaki BAZNAS Kota Bogormemiliki jumlah tanggungan 1-3 orang. Sedangkan untuk responden Muzaki Distribusi Langsung menunjukkan bahwa sebesar $66.67 \%$ atau sebanyak 20 orang responden Muzaki Distribusi Langsung memiliki jumlah tanggungan 1-3 orang.

\subsection{Alasan Membayarkan Zakat Langsung ke Mustahik}

Tabel 5 menampilkan alasan Muzaki Distribusi Langsung menyalurkan zakatnya langsung ke mustahik. Alasan yang ditampilkan adalah alasan paling kuat yang dipertimbangkan oleh muzaki. Sebanyak 23 orang atau $76.67 \%$ mengakui bahwa alasan mereka menyalurakan zakatnya tidak melalui lembaga adalah karena lebih mudah dan langsung ke sasaran. Hasil penelitian ini sesuai dengan pernyataan Mawardi (2005) bahwa muzaki yang membayarkan zakatnya langsung kepada mustahik memiliki beberapa alasan, diantaranya adalah terjadinya pembagian zakat yang rancu dan ganjil sehingga tidak semua mustahik mendapat bagian. Hal tersebut menyebabkan adanya persepsi muzaki bahwa OPZ belum mendistribusikan zakatnya secara luas. Adapun hasil penelitian ini sesuai dengan penelitian Mukhlis (2011) yang menyatakan bahwa muzaki memilih menyalurkan zakatnya langsung kepada mustahik karena akses yang lebih mudah dan langsung ke sasaran, serta tidak adanya sosialisasi mengenai lembaga zakat terhadap muzaki.

Tabel 5 Alasan Menyalurkan Zakat Langsung ke Mustahik

\begin{tabular}{lc}
\hline \multicolumn{1}{c}{ Alasan } & Persentase (\%) \\
\hline Lebih Mudah dan Langsung ke Sasaran & 76.67 \\
Tidak Ada Informasi Seputar OPZ & 6.67 \\
OPZ belum mendistribusikan zakat secara luas & 13.33 \\
Sesuai Syariat & 3.33 \\
\hline
\end{tabular}




\subsection{Mustahik Zakat}

Responden Muzaki Distribusi Langsung yang diwawancarai menyatakan bahwa mereka membayarkan zakatnya langsung kepada mustahik. Mustahik merupakan orang-orang yang berhak mendapatkan zakat. Mustahik Zakat yang paling banyak diberikan zakat oleh muzaki adalah anak yatim, yaitu 14 orang. Adapun 13 orang lainnya mengaku menyalurkan zakat kepada fakir miskin yang ada di sekitar tempat tinggal muzaki. Sedangkan beberapa muzaki menyatakan tidak pernah memberikan zakat kepada golongan khusus, melainkan hanya kepada siapapun yang membutuhkan.

Hasil penelitian menunjukkan bahwa Muzaki Distribusi Langsung tidak seluruhnya memberikan zakat kepada golongan yang berhak mendapatkan zakat, yaitu golongan ashnaf. Beberapa muzaki mengaku menyalurkan zakatnya kepada saudara dan orang yang membutuhkan. Dalam hal ini dapat disimpulkan bahwa zakat yang disalurkan oleh Muzaki Distribusi Langsung tidak seluruhnya tepat sasaran karena tidak seluruhnya termasuk ke dalam golongan ashnaf. Hal ini sesuai dengan teori yang dikemukakan oleh Hafidhuddin (2007) bahwa membayarkan zakat melalui lembaga mempunyai beberapa kelebihan yang salah satunya adalah zakat dapat tersalurkan kepada golongan yang tepat.

\subsection{Persepsi Muzaki terhadap Kinerja BAZNAS Bogor}

Persepsi muzaki terhadap kinerja BAZNAS Bogor penting diketahui agar BAZNAS Bogor mampu mengoptimalkan fungsinya dalam memberikan pelayanan dan fasilitas yang lebih baik, serta menyediakan program penyaluran zakat yang diinginkan masyarakat. Analisis persepsi muzaki terhadap kinerja BAZNAS Bogor dilakukan dengan analisis deskriptif, yaitu dengan melihat nilai mean yang terdapat pada variabel Program penyaluran zakat, kualitas pelayanan, dan fasilitas yang disediakan BAZNAS Bogor.

Nilai rata-rata dari setiap variabel dalam penelitian ini adalah 4,01. Sehingga ada empat variabel yang nilainya sudah diatas rata-rata, yaitu reliability, responsiveness, fasilitas, dan tangible. Ada pun tiga variabel lainnya yang berada dibawah rata-rata, yaitu peogram penyaluran zakat, assurance, dan emphaty. Gambar 1 menunjukkan bahwa nilai mean Reliability mendapatkan nilai mean tertinggi diantara variabel lainnya. Hal ini menunjukkan bahwa BAZNAS Bogor profesional dalam pelayanannya dan memiliki prosedur penerimaan dan pemanfaat yang sesuai dengan ketentuan berlaku. Nilai mean tertingggi pada variabel reliability adalah prosedur penerimaan yang sesuai ketentuan yang berlaku, yaitu menggunakan tanda bukti pembayaran, dicatat dalam data muzaki, serta membacakan doa sebagai akad dalam zakat.

Variabel responsiveness dan tangible mendapatkan nilai mean yang sama, yaitu 4,06. Variabel responsiveness menunjukkan bahwa BAZNAS Bogor sudah memiliki kesiapan dan ketanggapan yang baik saat memberikan pelayanan. Terutama dalam memberikan informasi zakat yang cepat dan tepat, karena sub-variabel tersebut mendapatkan nilai mean tertinggi. Variabel tangible menunjukkan bahwa bukti fisik atau penampilan sarana dan prasarana fisik dari BAZNAS Bogor sudah cukup baik. Nilai mean tertinggi pada variabel tangible adalah penampilan fisik dan kemampuan komunikasi amil di BAZNAS Bogor yang dinilai sangat baik oleh muzaki.

Hasil penelitian menunjukkan bahwa variabel fasilitas mendapatkan nilai mean sebesar 4,01 dengan nilai sub variabel tertinggi pada fasilitas membayarkan zakat menggunakan teknologi, yang artinya memudahkan muzaki dengan membayar zakat melalui mobile banking, transfer, dan credit card. Variabel emphaty mendapatkan nilai mean sebesar 3,98 yang artinya bentuk perhatian yang diberikan Amil kepada muzaki dan upaya-upaya untuk memahami keinginankeinginan muzaki sudah cukup baik. Nilai mean tertinggi berada pada kemampuan amil untuk 
menjaga hubungan yang baik dengan muzaki, yaitu dengan menjaga komunikasi yang baik dengan muzaki, berkirim pesan, dan memberikan perhatian berupa memberikan gift kepada muzaki.

Program penyaluran zakat mendapatkan nilai mean sebesar 3,9 yang artinya program penyaluran zakat yang disediakan BAZNAS Bogor dianggap sudah cukup baik oleh muzaki. Terutama dalam hal inovasi program dan kontribusinya bagi masyarakat. Variabel assurance mendapatkan nilai mean terendah, yaitu 3,86. Hal ini menunjukkan bahwa transparansi, kredibilitas, dan pengetahuan amil mengenai zakat sudah cukup baik, namun nilai mean terendah pada variabel tersebut adalah mengenai laporan pertanggungjawaban. Hal ini sejalan dengan survei sebelumnya yang menunjukkan bahwa $43 \%$ muzaki tidak pernah mendapatkan laporan pertanggungjawaban secara pribadi dari BAZNAS Bogor. Sehingga untuk meningkatkan tingkat assurance, BAZNAS Bogor perlu untuk meningkatkan transparansinya dan memberikan laporan pertanggungjawaban kepada muzaki sehingga menimbulkan kepercayaan muzaki.

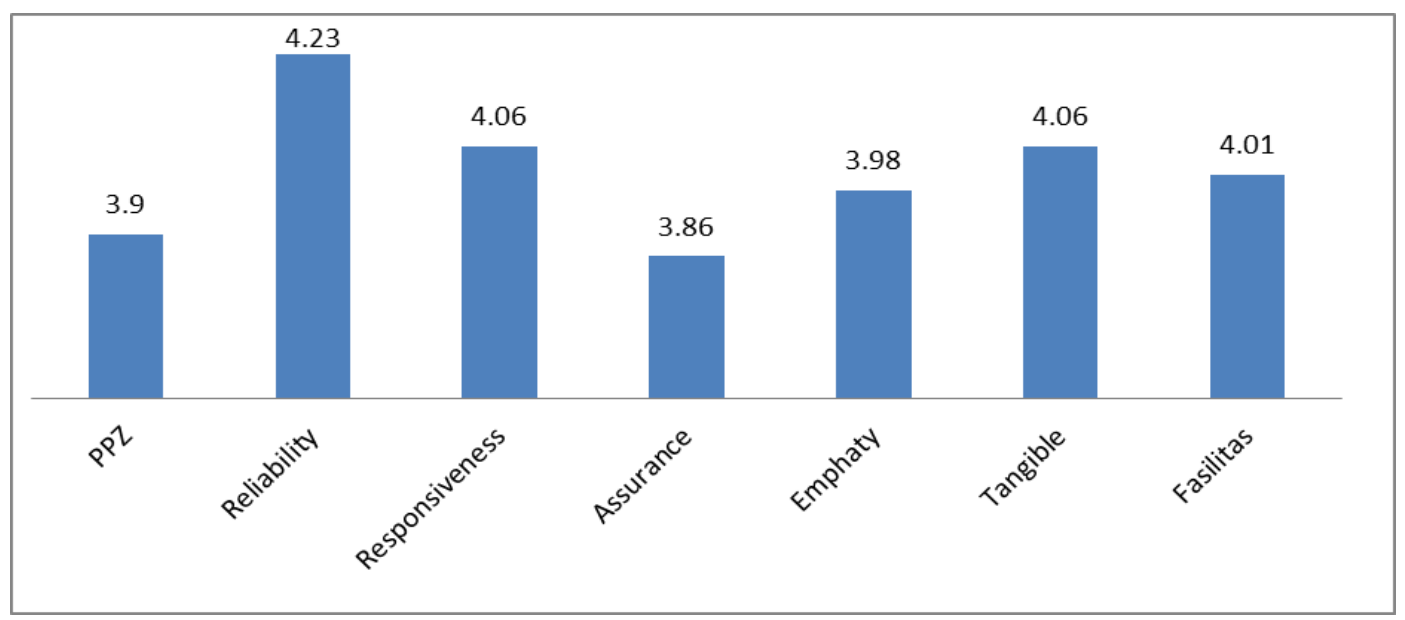

Gambar 1 Nilai mean masing-masing variabel

\subsection{Hasil Uji Beda}

Uji beda digunakan untuk mengetahui perbedaan rata-rata antara dua kelompok sampel yang berpasangan/berhubungan. Pada penelitian ini, uji beda dilakukan pada variabel antara responden muzaki BAZNAS dan Muzaki Distribusi Langsung. Hasil uji beda dapat dilihat pada Tabel 6 sebagai berikut :

Tabel 6 Hasil Uji Beda

\begin{tabular}{llrl}
\hline \multicolumn{1}{c}{ Variabel } & \multicolumn{1}{c}{$\begin{array}{c}\text { Mean } \\
\text { Difference }\end{array}$} & Standar Deviasi & P-Value \\
& 1.13333 & 14.46931 & 0.671 \\
Umur & 0.00000 & 2.37806 & 1.000 \\
Pendidikan & $8.7357 \mathrm{E} 5$ & $7.20371 \mathrm{E} 6$ & 0.512 \\
Pendapatan & 0.46667 & 1.94286 & 0.199 \\
Jumlah Tanggungan & 1.25000 & 9.72266 & 0.487 \\
Jarak & 1.13333 & 2.37419 & 0.014 \\
Pengetahuan & 2.56667 & 2.60878 & 0.000 \\
Citra Lembaga & 3.20000 & 4.86649 & 0.001 \\
Program Penyaluran Zakat & 4.36667 & 4.21396 & 0.000 \\
Reliability & & &
\end{tabular}

Jurnal Al-Muzara'ah, Vol. 3, No. 1 


\begin{tabular}{lcrl} 
Responsiveness & 2.73333 & 3.64770 & 0.000 \\
\hline \multirow{2}{*}{ Variabel } & $\begin{array}{c}\text { Mean } \\
\text { Difference }\end{array}$ & Standar Deviasi & P-Value \\
\hline Assurance & 2.73333 & 4.54808 & 0.003 \\
Emphaty & 6.36667 & 5.28161 & 0.000 \\
Tangible & 5.93333 & 5.09857 & 0.000 \\
Akses & 4.56667 & 5.58744 & 0.000 \\
Promosi Lembaga & 1.50000 & 3.18130 & 0.015 \\
\hline
\end{tabular}

Hasil uji beda menunjukkan bahwa skor emphaty mendapatkan nilai mean difference terbesar dibandingkan variabel lain. Hal ini menunjukkan bahwa hasil skor emphaty antara muzaki BAZNAS Kota Bogor dan muzaki distribusi langsung berbeda nyata. Artinya, muzaki BAZNAS Kota Bogor dapat memberikan skor emphaty yang lebih tinggi karena muzaki BAZNAS Kota Bogor benar-benar mengetahui tingkat emphaty BAZNAS Kota Bogor. Selanjutnya, variabel yang mendapatkan nilai mean difference terendah adalah jumlah tanggungan, artinya jumlah tanggungan muzaki BAZNAS Kota Bogor dan muzaki distribusi langsung tidak terlalu berbeda.

\subsection{Faktor-faktor yang Memengaruhi Muzaki dalam Memilih Organisasi Pengelola Zakat (OPZ)}

Untuk mewujudkan kesejahteraan masyarakat dan mengurangi kemiskinan melalui pengelolaan dana zakat, keberadaan OPZ sangat penting dalam membantu efisiensi dan efektivitas baik dalam penghimpunan maupun pendistribusian zakat. Hal tersebut dapat direalisasikan dengan meningkatkan kepercayaan muzaki terhadap OPZ, sehingga dana zakat yang terhimpun semakin besar serta mampu mendistribusikan zakatnya dengan lebih luas. Analisis faktorfaktor yang memengaruhi muzaki dalam memilih OPZ dilakukan dengan model logit. Tabel 3 menyajikan hasil pendugaan parameter dari model logit tersebut.

Tabel 7 Hasil Pendugaan Parameter Model Logit

\begin{tabular}{lccc}
\hline \multirow{2}{*}{ Observasi } & \multicolumn{2}{c}{ Prediksi } & $\begin{array}{c}\text { Percentage } \\
\text { Correct }\end{array}$ \\
\cline { 2 - 3 } & $\begin{array}{c}\text { Muzaki Distribusi } \\
\text { Langsung }\end{array}$ & $\begin{array}{c}\text { Muzaki } \\
\text { BAZNAS }\end{array}$ & \\
\hline Tidak Membayar Zakat di OPZ & 26 & 4 & 86.7 \\
Membayar Zakat di OPZ & 5 & 25 & 83.3 \\
\cline { 1 - 3 } Overall Percentage & & & 85.0 \\
\hline
\end{tabular}

Hasil pendugaan parameter diatas menyatakan bahwa model dapat mengklasifikasikan responden yang tidak membayar di OPZ sebesar $86.7 \%$ dan $83.3 \%$ yang membayar zakat di OPZ. Model pun mampu mengklasifikasikan secara keseluruhan responden yang membayar zakat di OPZ maupun tidak membayar di OPZ sebesar 85\%. Hasil uji Chi Square Hosmer dan Lemeshow Test menunjukkan nilai Chi Square sebesar 6.085 dengan p-value $0.638>0.05$ sehingga dapat disimpulkan bahwa model logit secara keseluruhan dapat menjelaskan faktorfaktor yang memengaruhi muzaki dalam memilih OPZ.

Variabel reliability atau kehandalan OPZ dalam memberikan pelayanan memiliki nilai odds ratio sebesar 1.764, berarti muzaki yang memiliki skor reliability lebih tinggi berpeluang untuk menyalurkan zakatnya 1.764 kali lipat lebih besar daripada muzaki yang memiliki skor reliability lebih rendah. Artinya, OPZ mampu memberikan pelayanan yang mudah, cepat, dan profesional, serta memiliki prosedur penerimaan dan pemanfaatan sesuai ketentuan yang 
berlaku,. Hal ini sesuai dengan penelitian Jaelani (2008) yang menyatakan bahwa kualitas pelayanan berpengaruh signifikan terhadap keputusan berzakat dan penelitian Muhammad et al. (2006) yaitu responden mau membayarkan zakat kepada organisasi karena mereka puas pada layanan yang ditawarkan oleh organisasi yang bertanggungjawab dalam pengumpulan zakat.

Variabel penghasilan memiliki nilai odds ratio sebesar 1.000, artinya Muzaki Distribusi Langsung maupun muzaki OPZ memiliki peluang yang sama untuk membayarkan zakatnya ke OPZ. Muzaki dengan tingkat penghasilan yang besar maupun kecil memiliki peluang yang sama untuk menyalurkan zakatnya ke OPZ. Hasil ini bertentangan dengan penelitian Ramadhani (2011) yang menyatakan bahwa tingkat pendapatan muzaki berpengaruh terhadap pemilihan tempat berzakat.

Tabel 8 Faktor-Faktor yang Memengaruhi Muzaki dalam Memilih Organisasi Pengelola Zakat (OPZ)

\begin{tabular}{|c|c|c|c|}
\hline \multirow{2}{*}{ Variabel } & \multicolumn{3}{|c|}{ Metode Logit } \\
\hline & Parameter & P-Value & Odds Ratio \\
\hline Konstanta & -12.965 & 0.009 & 0.000 \\
\hline Pendidikan & -0.021 & 0.923 & 0.979 \\
\hline Penghasilan & 0.000 & $0.069 *$ & 1.000 \\
\hline Pengetahuan & -0.272 & 0.385 & 0.762 \\
\hline Citra Lembaga & 0.406 & $0.095^{*}$ & 1.501 \\
\hline Reliability & 0.567 & $0.025^{* *}$ & 1.764 \\
\hline Responsiveness & 0.110 & 0.604 & 1.116 \\
\hline Akses & 0.063 & 0.683 & 1.065 \\
\hline Promosi Lembaga & -0.115 & 0.599 & 0.891 \\
\hline
\end{tabular}

Keterangan $\quad: *$ Signifikan pada taraf nyata 10 persen, **Signifikan pada taraf nyata 5 persen

Variabel citra lembaga memiliki nilai odds ratio sebesar 1.501, artinya muzaki yang memiliki skor citra lembaga lebih besar memiliki peluang untuk membayarkan zakatnya kepada OPZ 1.501 kali lebih besar dibanding muzaki yang memiliki skor citra lembaga lebih rendah. Artinya, keputusan untuk membayar zakat melalui OPZ dipengaruhi citra lembaga yang profesional, terpercaya, dikenal dan diminati banyak orang. Hasil penelitian ini sesuai dengan penelitian Mukhlis (2011) yang menyatakan bahwa muzaki yang membayarkan zakatnya di OPZ memiliki penilaian yang baik terhadap OPZ.

\section{Simpulan}

Berdasarkan hasil penelitian maka diperoleh beberapa kesimpulan. Pertama, Persepsi muzaki terhadap kinerja BAZNAS Kota Bogor sudah cukup baik. Hal ini dilihat dari nilai mean pada variabel program penyaluran zakat, reliability, responsiveness, assurance, emphaty, tangible, dan fasilitas yang menunjukkan nilai mean lebih besar dari tiga dari skala lima. Variabel yang mendapatkan nilai mean tertinggi adalah variabel reliability, artinya BAZNAS Kota Bogor memberikan pelayanan yang profesional, mudah, dan cepat, serta memiliki prosedur penerimaan dan pemanfaatan zakat yang sesuai dengan ketentuan yang berlaku. Walau demikian variabel yang mendapatkan nilai mean terendah adalah variabel assurance. Oleh karena itu sebaiknya laporan pertanggungjawaban atas penyaluran zakat diberikan secara personal kepada muzaki agar muzaki semakin percaya terhadap transparansi BAZNAS Kota Bogor. Kedua, Faktor-faktor yang memengaruhi muzaki dalam memilih OPZ adalah reliability dan citra lembaga dengan nilai odds ratio sebesar 1.704 dan 1.501. 
Berdasarkan hasil penelitian yang menunjukkan bahwa tingkat reliability OPZ, dan citra lembaga merupakan variabel yang memengaruhi muzaki dalam memilih OPZ. Oleh karena itu, ada empat rekomendasi saran yang diberikan berdasarkan penelitian. Pertama, OPZ dapat meningkatkan citra lembaga yang baik di mata masyarakat dengan cara terus meningkatkan kualitas pelayanannya, yaitu meningkatkan tingkat reliability, responsiveness, assurance, tangible, dan emphaty. Kedua, Persepsi muzaki mengenai tingkat assurance BAZNAS Kota Bogor mendapat nilai yang rendah, terutama pada poin laporan pertanggungjawaban. Oleh karena itu sebaiknya laporan pertanggungjawaban atas penyaluran zakat diberikan secara personal kepada muzaki agar muzaki semakin percaya terhadap transparansi BAZNAS Kota Bogor.

Ketiga, sebanyak $6.67 \%$ muzaki distribusi langsung mengaku tidak mendapatkan informasi mengenai OPZ. Oleh karena itu sebaiknya sosialisasi tentang manfaat dan keutamaan membayar zakat ke OPZ perlu ditingkatkan, karena sebagian muzaki tidak mengetahui bahwa membayar zakat ke OPZ dapat memberikan nilai manfaat yang lebih besar dibandingkan membayar zakat secara langsung. Keempat, sebanyak $13.33 \%$ muzaki mengaku memilih membayarkan zakatnya langsung ke mustahik karena OPZ belum mendistribusikan zakatnya secara luas. Oleh karena itu sebaiknya OPZ dapat menjalin kerjasama yang baik dengan muzaki mengenai informasi mustahik yang berhak mendapatkan dana zakat, sehingga OPZ dapat menyalurkan zakatnya lebih luas.

\section{Daftar Pustaka}

Amalia, E. 2010. Sejarah Pemikiran Ekonomi Islam. Gramata Publishing.

Arifin, G. 2011. Zakat, Infak, Sedekah : Dalil - Dalil dan Keutamaan. Elex Media Komputindo. [BAZNAS Bogor] Badan Amil Zakat Nasional Kota Bogor. 2013. Laporan Rekapitulasi Penerimaan Zakat, Infaq, dan Sedekah [ZIS]. BAZNAS Bogor.

Damanhuri, D.S. 2010. Ekonomi Politik dan Pembangunan : Teori, Kritik, dan Solusi bagi Indonesia dan Negara Sedang Berkembang. IPB Press.

Firdaus M, Harmini, Afendi FM. 2011. Aplikasi Metode Kuantitatif untuk Manajemen dan Bisnis. IPB Press.

Gamsir B, Ubud S, Armanu, Djumahir. 2012. Perilaku Muzakki dalam Membayar Zakat Mal (Studi Fenomenologi Pengalaman Muzakki di Kota Kendari). Jurnal Aplikasi Manajemen. Vol.10 No.2 Juni 2012. 431-435

Hafidhuddin, D. 2002. Zakat dalam Perekonomian Modern. Gema Insani. BAZNAS. 2005. Anda Bertanya tentang Zakat Infak dan Sedekah Kami Menjawab. 2007. Agar Harta Berkah dan Bertambah. Gema Insani.

2013. Bersatunya Lembaga Zakat, Sarana untuk Mempersatukan Umat. [internet]. [15 Maret 2013]. BAZNAS. Tersedia pada: http://pusat.baznas.go.id/beritaartikel/bersatunya-lembaga-zakat-sarana-untuk-mempersatukan-umat/

Hidayat, M. 2010. An Introduction to Sharia Economic. Zikrul Hakim.

Jaelani, A. 2008. Pengaruh Kualitas Pelayanan dan Social Marketing Lembaga Amil (LAZ) terhadap keputusan berzakat Muzakki (Studi Kasus pada Rumah Zakat Indonesia) [tesis]. Universitas Indonesia.

Juanda, B. 2009. Ekonometrika Permodelan dan Pendugaan. IPB Press.

Mawardi. 2005. Strategi Efektivitas Peran Lembaga Zakat di Indonesia. Jurnal Hukum Islam. Vol. IV No.2. 3

Muhammad. 2009. Lembaga Keuangan Mikro Syariah. Graha Ilmu.

Mukhlis, A. 2011. Analisis Faktor-Faktor Yang Memengaruhi Tingkat Kepatuhan Membayar Zakat : Studi Kasus Kabupaten Bogor [skripsi]. Institut Pertanian Bogor.

Qardhawi, Y. 1993. Hukum Zakat. Volume ke-1. Harun S, Hafidhuddin D, Hasanuddin, penerjemah. Litera AntarNusa. 
Rulian NA, Anggraeni L, Lubis D Faktor yang Memengaruhi Muzaki Memilih OPZ

Ramadhani, N.F. Analisis Faktor-Faktor Yang Mempengaruhi Pengumpulan Zakat, Infaq dan Shoddaqoh pada Badan Amil Zakat Daerah Sumatera Utara (BAZDA SUMUT) [Skripsi]. Universitas Sumatera Utara 